\section{THE DISCOVERY OF THE LARVA OF THE COMMON EEL.}

THE first Leptocephalus was discovered in 1763 , when a specimen was taken near Holyhead, by $\mathrm{Mr}$. William Morris, and sent to Pennant. Since that time numerous specimens, having similar characters, have been obtained on the shores of Britain, in the Mediterranean, and at the surface of the ocean in various parts of the world. The chief peculiarities of these creatures, which have long been considered much more extraordinary than they really are, are the following. The the common eel. They hat not been able to follow the entire metamorphosis in one and the same specimen; but they had verified the most important changes in specimens kept in confinement, and compared all the organs in various stages with those in the perfect form. The greatest length of the larva is $8 \mathrm{~cm}$., or $3 \frac{1}{4}$ in., and the reduction after transformation is never more than $3 \mathrm{~cm}$., so that the smallest elver, or young fully-developed eel, is 2 in. long.

A fuller account of this most interesting investigation was communicated by Prof. Grassi to the Royal Society last year, and is published in the Proceedings of

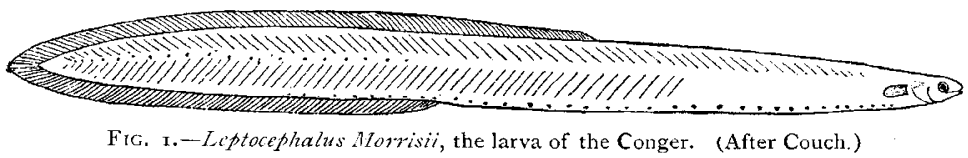

body is several inches in length, thin and of uniform breadth like a piece of ribbon, very transparent, and unpigmented. The head is small in proportion; there are pectoral fins, but no pelvic, and there is a narrow fin running along the edge of the body, above and below, to the tail. The blood is not red, and there is no airbladder. Internally the body consists largely of a peculiar gelatinous tissue.

The surgestion that the Leptocephati were the normal larvie of fishes of the eel family, was first made by the American ichthyologist, Gill, in 1864 . In 1886 Yves Delage proved experimentally that L. Morrisii changed into a young conger.

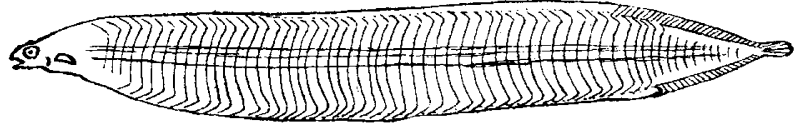

FI(i. 2.-Leptocephalus bevirostris, the larva of the Eel. (After the original figure in Kaup's Catalogue of Apodal Fish, 1856 .)

In 1892 Grassi and Calandruccio published their first paper on these forms, giving a brief and summary account of the results of observations at Catania. They had obtained a large number of living specimens from the harbour of Catania, and had succeeded in keeping them alive for varying periods in aquaria. The specimens belonged to several of the "species" which had previously been distinguished and named, and their metamorphosis into specimens of various species of Murænidæe was traced with complete, or nearly complete, continuity in a number of cases. Thus the complete metamorphosis of L. Morrisii into
December 1896, and also in the Quarterly Journ. Mic Sci. of November 1896. It is well known that in the Straits of Messina strong currents and whirlpools occur. To the existence of these disturbances of the water, the occasional occurrence of various stages in the development of Muræenoids in the surface water is to be attri buted. As the Leptocephali are captured in company with fish of various species known to belong to the deepsea fauna, it is inferred that the spawning of the eel and other Muranidx, and the development of the eggs and larvae, take place normally at great depths - at least 500 metres (250 fathoms) - and that the larvic are carried to the surface with deep-sea fishes by the movements of the water just mentioned. Specimens of Murana helena with ripe eggs, and of adult eels, both male and fenale, have also been captured under the same circumstances. In these adult eels the generative organs are sometimes more developed than in specimens otherwise obtained, and in some of the males ripe spermatozoa have been observed for the first time. A ripe male conger was described in $188 \mathrm{r}$ by Otto Hermes, and several were kept alive by the present writer in the Plymouth Aquarium, but ripe male eels had never before been obtained.

These mature, or nearly mature, eels are remarkable for the large size of their eyes; and similar specimens, previously obtained from deep water, were described as distinct species by Kaup. The mature male conger is also distinguished by the greater size of its eyes. In the mature eels, also, the skin of the belly is silvery, not yellow, as in river eels.

Raffaele, in his valuable paper on the pelagic eggs and larve of fishes in the Gulf of Naples, published in the Mittheilungen of the Naples Station in I888, de-

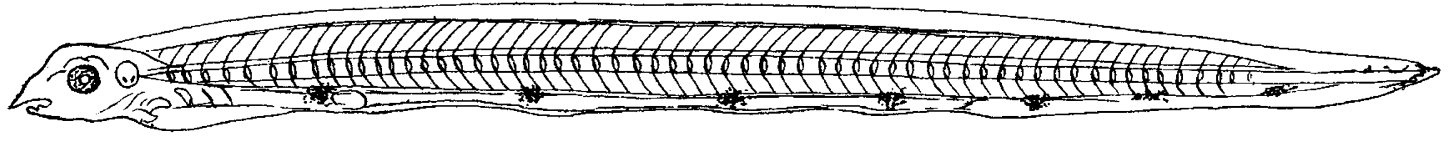

Fig. 3.-Young Leptocephalus, hatched in the aquarium, as it appears after the absorption of the yolk. Actual length, $9^{*} \mathrm{I}$ mn. (After Raffaele.)

young congers was traced in I 50 individuals, larve $5 \mathrm{in.}$ long being reduced to conger of only 3 in. L. diaphanus became Congromurcena balearica, L. Köllikeri, Yarrellii, Haeckeli, and other forms proved to be all stages in the normal development of Congromurene mystax, and $L$. Kefersteini changed into Ophichthys serpens.

Leptocephali are most frequently taken in the Straits of Messina, and amongst the forms there obtained is one named $L$. brevirostris, which is remarkable for its small size, and the entire absence of specks of pigment. In 1893 Grassi and Calandruccio announced that they had proved that this particular form was the larva of scribed five different kinds of pelagic eggs which had certain common characters, and which, in his opinion, possibly belonged to various species of the Murenidr. Raffaele described the larva hatched from one of these eggs, and it has the essential characters of a Leptocephalus. Grassi considers that one kind of these eggs, which has no oil-globules, is that of the common eel. But he believes that the eggs, like the larvæ, are only occasionally brought to the surface, and that they normally remain at great depths.

It is a curious fact that the larve, now identified as those of the eel, are found in greatest abundance in the

NO. I 429, VOL. 55$]$ 
stomach of the sun-fish (Orthagoriscus mola), which Grassi believes to be a deep-sea species. In the Straits of Messina this fish rarely appears, except in the months from February to September, and the occurrence of $L$. brevirostris is limited to that period. The eggs, which evidently belong to Murzenida, are found in the sea from August to January ; the adult eels in an advanced stage of sexual development have been obtained from November to July; while, lastly, the migration of eels from fresh waters to the sea takes place from October to January. Thus Grassi traces backwards the succession of events in the origin and development of young eels, and reaches the conclusion that the elvers or eelfare which ascend rivers are already about a year old. The metamorphosis occupies one month. The eels which descend to the sea in winter take some months to ripen their sexual products. The eggs are fertilised in August and following months, and the larvæ are found in the following spring and summer. This agrees with the facts that have been established concerning the conger, the female of which takes about six months to develop her ovaries, and during this period takes no food. The eels which migrate to the sea in autumn have the generative organs in a quite immature condition, and, therefore, could not well be the parents of the elvers, which begin to ascend rivers in the following February. It would appear, however, from Grassi's paper, that he considers the metamorphosis to take place in winter, and that by one year old, he means derived from the larvæ of the previous summer; so that two years would elapse between the descent of the adult eels and the ascent of their progeny.

\section{J. T. Cunningham.}

\section{NOTES}

THE death of Prof. J. J. Sylvester, on Monday, deprives mathematical science of a most brilliant mind, and the scientific world in general of one of its foremost workers. The greatness of his genius has long been recognised wherever pure mathematics is studied; for his works command admiration by their originality and breadth of treatment. Eight years ago, Prof. Sylvester was added to the NATURE Series of "Scientific Worthies," and an account was then given of his career and of his more important contributions to mathematical science. We merely call attention to this article now, deferring until our rext issue a fuller notice of the life and work of the esteemed investigator just lost to science.

M. G. Bonnier has been elected a member of the Section of Botany of the Paris Academy of Sciences, in succession to the late M. Trécul.

The library of the late Prof. Kekulé, of Bonn, containing eighteen thousand volumes, mostly on chemistry, has been purchased by the firm of Messrs. Friedrich Bayer and Co., dye manufacturers, Elberfeld.

THE Russian Government has conferred the Order of St. Stanislas upon M. Moureaux, the director of the magnetic work at the Parc St. Maur Observatory. M. Moureaux has also been awarded a gold medal by the (ieographical Society at St. Petersburg.

A "Discussion" meeting of the Royal Society will be held on Thursday next, March 25. The subject for discussion is the chemical constitution of the stars, and it will be introduced by Mr. J. Norman Lockyer, C.B., F.R.S., with a communication "On the Chemistry of the Hottest Stars."

THE annual meeting of the Iron and Steel Institute will be held on Tuesday and Wednesday, May II and 12. At this meeting the Bessemer gold medal for $\mathrm{I} 897$ will be presented to
Sir Frederick A. Abel, Bart., K.C.B., F.R.S. The autumn meeting of the Institute will be held at Cardiff, August Io to 13 .

A REUTER telegram from Christiania states that the Financial Committee of the Norwegian Storthing has unanimously adopted a proposal in favour of granting 4000 kroner to each of Dr. Nansen's twelve companions, and 3000 kroner yearly during a period of five years to Captain Sverdrup, who will be at the head of the next expedition in the Fram planned by Dr. Nansen for 1898 .

The Howard Medal of the Royal Statistical Society, together with a cheque for 2ol., was presented to Dr. James Kerr, at the meeting of the Society on Tuesday, for his essay on "School Hygiene, in its Mental, Moral, and Physical Aspects."

TrE Berlin Academy of Sciences offers a prize of $2000 \mathrm{~m}$. for the best treatise on the origin and characters (Entstehung $u$. Verhalten) of the varieties of cereals during the past twenty years. The essays, which may be written in German, French, English, Italian, or Latin, must be sent in by December 3I, 1898 .

THF American Commission for the selection of a site for a Tropical Botanical Laboratory has now been constituted as follows :--Prof. D. H. Campbell (Leland Stanford University), Prof. J. M. Coulter (University of Chicago), Prof. W. G. Farlow (Harvard University), Prof. D. T. MacDougal (University of Minnesota).

Considerable damage to gas and water pipes by electrolysis, due to the escape of the electric current used to propel trolley cars, is noted in Brooklyn. An illustration of the action of electricity was shown in a gas pipe two feet below the rail ; the pipe having been found with a gap an inch wide in it, and the edges eaten down to the thickness of a sheet of paper.

President Creveianis celebrated the one hundred and sixty-fifth anniversary of the birth of George Washington on Monday, February 22, by setting apart thirteen forest reservations on the recommendation of Secretary Francis and a forestry commission of the National Academy of Sciences appointed by Prof. Wolcott Gibbs, President of the Academy. The reservations have an aggregate area of $21,379,840$ acres.

TIE Bertilion system of anthropometrical measurements is now applied to criminals in New York City.

ThE veteran Italian botanist, Prof. T. Caruel, has retired from the professorship of Botany at the University of Florence.

ON Thursday next, March 25, Prof. W. Boyd Dawkins, F.R.S., will begin a course of three lectures at the Royal Institution on "The Relation of Geology to History." The Friday evening discourse on March 26 will be delivered by Sir William Turner, F.R.S., his subject being "Early Man in Scotland."

WE regret to have to record the death of Prof. Henry Drummond, the author of "Natural Law in the Spiritual World," "The Ascent of Man," and other works aiming at the reconciliation of theological revelation with science and evolution. He travelled in many parts of the world, and his "Tropical Africa" contains a very readable account of his journeys in the interior of that continent. With Sir Archibald Geikie he went on a geological expedition to the Rocky Mountains, and he more recently visited Australia, Java, Japan,

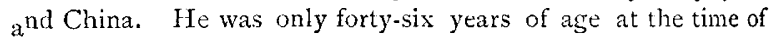
his death.

Tine Report of the Meteorological Council for the year I $895^{-96}$ has just been presented to Parliament, and is, as usual,

NO. I 429, VOL. 55] 